Volume 1 Nomor 2, Agustus 2016, halaman 135-148

\title{
PEMBELAJARAN MATEMATIKA DENGAN PENDEKATAN PROBLEM BASED LEARNING UNTUK MENGURANGI KECEMASAN MATEMATIKA DAN MENINGKATKAN KEMAMPUAN PEMECAHAN MASALAH MATEMATIS SISWA MTs
}

\author{
Ana Setiani \\ Universitas Muhammadiyah Sukabumi, ana.setiani.math@gmail.com
}

\begin{abstract}
ABSTRAK
Penelitian ini bertujuan untuk melakukan studi yang berfokus pada pengaruh model pembelajaran yang diduga dapatmengurangi kecemasan matematika dan meningkatkan kemampuan pemecahan masalah matematis siswa. Instrumen yang digunakan dalam penelitian ini adalah tes kemampuan pemecahan masalah matematis serta angket kecemasan matematika dengan skala likert. Analisis data menggunakan metode Mixed Method Embedded Konkuren. Berdasarkan analisis data diperoleh kesimpulan bahwa (1) Terdapat peningkatan kemampuan pemecahan masalah matematis siswa dengan Problem Based Learning lebih baik daripada siswa dengan pembelajaran ekspositori. (2) Terdapat peningatan kualitas kemampuan pemecahan masalah matematis siswa yang menggunakan Problem Based Learning lebih baik daripada siswa dengan pembelajaran ekspositori. (3) Terdapat perbedaan yang signifikan kecemasan matematika dan pencapaian kemampuan pemecahan masalah matematis siswa dengan Problem Based Learning dan siswa dengan pembelajaran ekspositori, (4) Terdapat perbedaan yang signifikan penurunan kecemasan matematika dan peningkatan kemampuan pemecahan masalah matematis siswa dengan pembelajaran Problem Based Learning dam siswa dengan pembelajaran ekspositori, dan (5) Terdapat hubungan yang signifikan antara kecemasan matematika dengan pencapaian kemampuan pemecahan masalah matematis siswa.
\end{abstract}

Kata Kunci: Kecemasan Matematika, Kemampuan Pemecahan Masalah Matematis,

\section{ABSTRACT}

The aims of this research are focused to examine the effect of learning model was estimated to decrease mathematics anxiety and to increase student's mathematical problem solving ability. The instrument that used for this research were ability test of problem solving in math and mathematics quosionaire with likert scale. The data analysis used mixed method embedded konkruen method. Based on data analysis concluded (1) the result show the increasing student's mathematical problem solving ability by problem based learning model better than by expository teaching; (2) increasing quality of studen'ts mathematical problem solving ability by problem based learning better than by expository teaching. (3) significant differences between mathematics anxiety and the accomplisment of student's matematical problem solving ability by problem based learning and by expository teaching (4) significant differences between decreasing mathematics anxiety and increasing of student's mathematical problem solving ability by problem based learning and by expository teaching. and (5) there is significan relationship between mathematics anxiety and the accomplishment of student's mathematical problem solving ability.

Keywords: Mathematics Anxiety, Problem Solving, Problem Based Learning. 
Problem Based Learning.

\section{How to Cite: Setiani, A. (2016). Pembelajaran Matematika dengan Pendekatan Problem Based Learning untuk Mengurangi Kecemasan Matematika dan Meningkatkan Kemampuan Pemecahan Masalah Matematis Siswa MTs. Mathline: Jurnal Matematika dan Pendidikan Matematika, Vol.1, No.2, 135- 148.}

\section{PENDAHULUAN}

Pada saat ini kurikulum yang berlaku di Indonesia adalah kurikulum 2013 dengan tujuan sebagai pelengkap kurikulum 2006 yang telah dipakai sebelumnya. Kurikulum 2013 adalah usaha yang terpadu antara (1) rekonstruksi kompetensi lulusan, dengan (2) kesesuaian dan kecukupan, keluasan dan kedalaman materi, (3) revolusi pembelajaran dan (4) reformasi penilaian. Kurikulum tersebut disusun berdasarkan atas potensi dan karakteristik setiap daerah serta kondisi sosial budaya dan karakteristik masing-masing siswa. Selain itu, melalui kurikulum ini juga diharapkan guru dapat mengembangkan dan menyiapkan sendiri bahan ajar yang akan disampaikan, hal tersebut dapat meningkatakan kreatifitas dan kualitas dari guru tersebut.

Depdiknas (2006) mata pelajaran matematika dipelajari pada setiap senjang pendidikan termasuk pada jenjang pendidikan menengah pertama. Sebagai mata pelajaran yang dipelajarai pada jenjang pendidikan menengah pertama, pelajaran matematika memiliki tujuan seperti yang tercantum dalam Permendiknas Nomor 22 Tahun 2006 bahwa pelajaran matematika bertujuan agar peserta didik memiliki kemampuan sebagai berikut: (1) Memahami konsep matematika, menjelaskan keterkaitan antar konsep dan mengaplikasikan atau lograitma secara luwes, akurat, efesien, dan tetap dalam pemecahan masalah. (2) Menggunakan pola dan penalaran pada pola dan sifat, melakukan manipulasi matematika dalam membuat generalisasi, menyusun bukti, atau menjelaskan gagasan dan pernyataan matematika. (3) Memecahkan masalah yang meliputi kemampuan masalah, merancang model matematika, menyeleaikan model, dan menafsirkan solusi yang diperoleh. (4) Mengkomunikasikan gagasan dengan simbol, tabel, diagram, atau media lain untuk memperjelas keadaan atau masalah. (5) Memiliki sikap menghargai kegunaan matematika dalam kehidupan yaitu memiliki rasa ingin tahu, perhatian, dan minat dalam mempelajari matematika, serta sikap ulet dan percaya diri dalam pemecahan masalah. 
Untuk membawa tujuan pembelajaran matematika di atas kearah yang dapat mengurangi kecemasan matematika dan meningkatkan kemampuan pemecahan masalah dan aplikasi konsep matematika yang optimal, pembelajaran harus berangkat dari pembelajaran yang memuat peserta didik aktif. Dengan demikian perlu adanya upaya untuk mencari dan menerapkan dengan sungguh-sungguh suatu hasil penelitian tentang model-model pembelajaran matematika yang dapat melibatkan peserta didik secara aktif sehingga mampu mengurangi kecemasan matematika dan meningkatkan kemampuan pemecahan masalah matematis.

Model pembelajaran Problem Based Learning berlandaskan pada psikologi kognitif, sehingga fokus pengajaran tidak begitu banyak pada apa yang sedang dilakukan siswa, melainkan kepada apa yang sedang mereka pikirkan pada saat mereka melakukan kegiatan. Pada Problem Based Learning peran guru lebih berperan sebagai pembimbing dan fasilitator sehingga siswa belajar berpikir dan memecahkan masalah mereka sendiri. Belajar berbasis masalah menemukan akar intelektualnya pada penelitian John Dewey (Ibrahim, 2000). Pedagogi Jhon Dewey menganjurkan guru untuk mendorong siswa terlibat dalam proyek atau tugas yang berorientasi masalah dan membentu mereka menyelidiki masalah-masalah tersebut. Pembelajaran yang berdayaguna atau berpusat pada masalah digerakkan oleh keinginan bawaan siswa untuk menyelidiki secara pribadi situasi yang bermakna merupakan hubungan Problem Based Learning dengan psikologi Dewey.

Sebagaimana disarankan oleh Ausubel (Ruseffendi, 2006) bahwa sebaliknya dalam pembelajaran digunakan pendekatan yang menggunakan metode pemecahan masalah, inkuiri dan metode belajar yang dapat menumbuhkan berpikir kreatif dan kritis, sehingga siswa mampu menghubungka dan memecahkan masalah matematis, pelajaran lainnya ataupun masalah yang berkaitan dengan kehidupan nyata. Dalam proses mengembangkan kemampuan pemecahan masalah matematis dan mengurangi kecemasan matematika siswa sekolah menengah pertama (SMP/MTs) tidaklah mudah. Hasil penelitian terdahulu menujukan bahwa kemampuan pemecahan masalah dengan apa yang diharapkan masih jauh. Permasalahanpermasalahan tersebut didukung dengan data hasil ulangan matematika selama tiga tahun terakhir yang mengalami fluktuatif dan cenderung menurun pada tahun terkhir, seperti tampak pada table berikut:

Tabel 1. Hasil Nilai Ulangan Harian Pelajaran Matematika 3 Tahun Terakhir 


\begin{tabular}{cccc}
\hline Hasil/Tahun & $\mathbf{2 0 1 0 /}$ & $\mathbf{2 0 1 1 /}$ & $\mathbf{2 0 1 2 /}$ \\
Pelajaran & $\mathbf{2 0 1 1}$ & $\mathbf{2 0 1 2}$ & $\mathbf{2 0 1 3}$ \\
\hline Nilai rata-rata & 68,00 & 63,00 & 56,13 \\
Nilai Tertinggi & 85,00 & 78,00 & 73,00 \\
Nilai Terendah & 45,00 & 40,00 & 30,00 \\
Standar Deviasi & 12,43 & 10,69 & 11,98 \\
\hline
\end{tabular}

Sumber: data ulangan harian MTs Atta'Zhimiyah

Dengan memperhatikan masalah-masalah yang telah diuraikan di atas dipeoleh fakta bahwa masalah rendahnya kemampuan pemecahan masalah matematis dan kecemasan matematika siswa MTs. Maka dalam penelitian ini penulis akan memberikan tidakantindakan dalam upaya untuk meningkatkan kualitas pembelajaran yang akan bermuara pada peningkatan untuk memperbaiki kinerja sebagai guru sehingga kecemasan matematika dan kemampuan pemecahan matematis siswa MTs dapat diatasi. Dari tujuan tersebut dapat disimpulkan bahwa fokus utama penelitian ini adalah untuk mengurangi kecemasan matematika dan meningkatkan kemampuan pemecahan masalah matematis siswa MTs.

Kunter (1992) menegaskan bahwa guru dan orang tua yang takut matematika bisa menularkan kecemasan matematika untuk generasi berikutnya, bukan genetik, tetapi dengan pengajaran yang salah dan tidak nyamanpun bisa menimbulkan kecemasan matematika bagi siswa. Sedangkan Richardson dan Suinn (1972) meyatakan bahwa kecemasan matematika melibatkan perasaan tegang dan cemas yang mempengaruhi dengan berbagai cara ketika menyelesaikan soal matematika dalam kehidupan nyata dan akademik.

Menurut Sumarmo (Yaniawati, 2001) pemecahan masalah dalam pembelajaran matematika dapat berupa soal cerita atau soal tidak rutin, yaitu soal yang untuk sampai pada prosedur yang benar diperlukan pemikiran yang mendalam, mengaplikasikan matematika dalam kehidupan sehari-hari dan membuktikan dalam kehidupan sehari-hari akan lebih terasa manfaatnya oleh siswa sehingga kecemasan matematika dapat berkurang, disamping itu , kemampuan pemecahan masalah siswa dapat meningkatkan kemampuan berpikir kritis, logis, sistematis dan kreatif.

Dari paparan di atas, begituh besar manfaat kemampuan pemecahan masalah untuk mengurangi tingkat kecemasan matematika oleh kerena itu perlu adanya suatu upaya pembelajaran yang mengarahkan siswa pada kemampuan pemecahan masalah tersebut. Problem Based Leraning merupakan salah satu model pembelajaran yang diduga dapat mengurangi kecemasan matematika dan meningkatkan pemecahan masalah matematis siswa. 
Berdasarkan latar belakang yang telah dikemukaan di atas, maka peneliti tertarik untuk melakukan studi yang berfokus pada pengaruh model pembelajaran yang diduga dapat mengurangi kecemasan matematika dan meningkatkan kemampuan pemecahan masalah matematis siswa, dalam hubungan ini, penulis mengadakan penelitian dengan judul : "Pembelajaran Matematika dengan Pendekatan Problem Based Learning untuk Mengurangi Kecemasan Matematika dan Meningkatkan Kemampuan Pemecahan Masalah Matematis Siwa MTs.".

\section{METODE PENELITIAN}

Metode penelitian yang digunakan dalam penelitian ini menggunakan strategi Mixed Method Embedded Konkuren, Strategi Embedded konkuren memiliki metode primer yang memandu proyek dan database sekunder yang memaninkan peran pendukung dalam prosedur-prosedur penelitian (Creswell, 2010).

Sampel yang digunakan dalam penelitian ini sebanyak dua kelas (kelas ekperimen dan kelas kontrol). Desain penelitian yang digunakan dalam penelitian ini adalah pretest-postest control group design, kemudian memilih dua kelas yang setara di tinjau dari kemampuan akademiknya. Kelas yang pertama melakukan pembelajaran Problem Based Learning (kelas eksperimen) dan kelas dengan pembelajaran ekspositori (kelas kontrol). Instrumen yang digunakan dalam penelitian ini terdiri dari angket mengenai kecemasan matematika siswa dan soal uraian yang mengukur kemampuan pemecahan masalah matematis. Kedua sampel diberikan pre-test dan post-test, kemudian dilihat penurunan kecemasan matematika dan peningkatan kemampuan pemecahan masalahnya. Data penurunan kecemasan matematika dan peningkatan kemampuan pemecahan masalah inilah yang nantinya akan dianalisis

Instrument tes yang digunakan adalah tes uraian kemampuan pemecahan masalah yang berisi 6 butir soal. Masing-masing butir soal mencakup 4 indikator kemampuan pemecahan masalah. Instrument tes ini memiliki koefisien reliabilitas $r=0.58$, dan masingmasing butir soal memiliki koefisien validitas berturut-turut $0.263,0.596,0.582,0.781$, $0.586,0.671$.

Penelitian ini dilaksanakan sebanyak 5 kali pertemuan tatap muka, dan 1 kali pertemuan khusus melakukan pre-test dan post-test. Masing-masing pertemuan berdurasi 2x40 menit. Selanjutnya, kelas eksperimen diberikan bahan ajar dengan model ProblemBased Learning. 


\section{HASIL DAN PEMBAHASAN}

Penelitian yang dilakukan menghasilkan beberapa data, yaitu diantaranya data kuantitatif berupa hasil tes kemampuan pemecahan masalah matematis, dan data kualitatif berupa hasil angket kecemasan matematika, dan hasil observasi.

Tabel 2. Pretes Kemampuan Pemecahan Masalah Matematis

\begin{tabular}{lrrr}
\hline & & Pretes Kelas Eksperimen & Pretes Kelas Kontrol \\
\hline $\mathrm{N}$ & Valid & 40 & 40 \\
& Missing & 58 & 58 \\
Mean & 43.1000 & 33.8750 \\
Median & 43.0000 & 32.5000 \\
Mode & 45.00 & 30.00 \\
Std. Deviation & 12.37408 & 10.58104 \\
Variance & 153.118 & 111.958 \\
Range & 43.00 & 46.00 \\
Minimum & 22.00 & 17.00 \\
Maximum & 65.00 & 63.00 \\
Sum & 1724.00 & 1355.00 \\
\hline
\end{tabular}

Berdasarkan tabel di atas rerata kedua kelas tersebut berbeda, kelas ekperimen lebih unggul 9,225 dibandingkan kelas kontrol. Untuk melihat apakah perbedaannya signifikan atau tidak, maka dilakukan tahap kedua yaitu analisis statistik parametrik, diantaranya uji normalitas dan homogenitas.

Tabel 3. Uji Normalitas Data Pretes Kemampuan Pemecahan Masalah Matematis

\begin{tabular}{lrrr}
\hline & \multicolumn{3}{c}{ Shapiro-Wilk } \\
\cline { 2 - 4 } & Statistic & df & Sig. \\
\hline Pretes Kelas Eksperimen & .962 & 40 & .200 \\
Pretes Kelas Kontrol & .961 & 40 & .180 \\
\hline
\end{tabular}

Nilai signifikansi kelas eksperimen dan kelas kontrol masing-masing 0,200 dan 0,180. Nilai signifikansi keduanya lebih besar dari 0,05 sehingga Ho diterima, artinya data pretes kelas eksperimen dan kelas kontrol berdistribusi normal.

Tabel 4. Uji Homogenitas Data Pretes Kemampuan Pemecahan Masalah Matematis

$\begin{array}{lllll}\text { Levene Statistic } & \text { df1 } & \text { df2 } & \text { Sig. }\end{array}$

\begin{tabular}{llll}
1.723 & 1 & 78 & .193 \\
\hline
\end{tabular}


Karena nilai signifikasi yang diperoleh 0,193>0,05 maka $\mathrm{H}_{0}$ diterima, sehingga data kedua kelas tersebut homogen.

Tabel 5. Uji t Data Pretes Kemampuan Pemecahan Masalah Matematis

\begin{tabular}{|c|c|c|c|c|c|c|c|c|}
\hline & \multicolumn{7}{|c|}{ t-test for Equality of Means } \\
\hline & & \multirow[t]{2}{*}{$\mathbf{T}$} & \multirow[t]{2}{*}{ Df } & \multirow[t]{2}{*}{$\begin{array}{l}\text { Sig. (2- } \\
\text { tailed) }\end{array}$} & \multirow[t]{2}{*}{$\begin{array}{c}\text { Mean } \\
\text { Difference }\end{array}$} & \multirow[t]{2}{*}{$\begin{array}{c}\text { Std. } \\
\text { Error } \\
\text { Difference }\end{array}$} & \multicolumn{2}{|c|}{$\begin{array}{c}\text { 95\% Confidence } \\
\text { Interval of the } \\
\text { Difference }\end{array}$} \\
\hline & & & & & & & Lower & Upper \\
\hline & $\begin{array}{l}\text { Equal } \\
\text { variances }\end{array}$ & 3.584 & 78 & .001 & 9.225 & 2.574 & 4.100 & 14.349 \\
\hline Pretes & $\begin{array}{l}\text { assumed } \\
\text { Equal } \\
\text { variances not } \\
\text { assumed }\end{array}$ & 4.089 & 76.167 & .001. & 9.225 & 2.574 & 4.098 & 14.351 \\
\hline
\end{tabular}

Dari tabel di atas terlihat bahwa nilai sig (2-tailed)nya $0,001<0,05$. Artinya rerata pretes kemampuan pemecahan masalah matematis kelas eksperimen dan kelas kontrol berbeda.

Tabel 6. Postes Kemampuan Pemecahan Masalah Matematis

\begin{tabular}{lrrr}
\hline & & Postes Kelas Eksperimen & Postes Kelas Kontrol \\
\hline $\mathrm{N}$ & Valid & 40 & 40 \\
& Missing & & 58 \\
Mean & 58 & & 65.5250 \\
Median & & 75.4250 & 66.0000 \\
Std. Deviation & 74.0000 & 7.94206 \\
Variance & 6.59793 & 63.076 \\
Range & 43.533 & 33.00 \\
Minimum & 28.00 & 45.00 \\
Maximum & 65.00 & 78.00 \\
Sum & 93.00 & 2621.00 \\
\hline
\end{tabular}

Berdasarkan tabel di atas, rerata kedua kelas tersebut berbeda, kelas eksperimen lebih unggul 9,900 dibandingkan kelas kontrol. Untuk melihat apakah perbedaannya signifikan atau tidak, maka dilakukan tahap kedua yaitu analisis statistik parametrik, diantaranya uji normalitas dan homogenitas.

Tabel 7. Hasil Uji Normalitas Data Postes Kemampuan Pemecahan Masalah Matematis 


\begin{tabular}{lccr} 
& & Df & Sig. \\
\cline { 2 - 4 } Pretes Kelas Eksperimen & .952 & 40 & .087 \\
Pretes Kelas Kontrol & .952 & 40 & .090 \\
\hline
\end{tabular}

Nilai signifikansi kelas eksperimen dan kelas kontrol masing-masing 0,087 dan 0,090. Nilai signifikansi keduanya lebih besar dari 0,05 artinya data postes kelas eksperimen dan kelas kontrol berdistribusi normal.

Tabel 8. Uji Homogenitas Data Postes Kemampuan Pemecahan Masalah Matematis

\begin{tabular}{ccccccr}
\hline Levene Statistic & & df1 & df2 & \multicolumn{2}{c}{ Sig. } \\
\hline & .583 & & 1 & & 78 & .447 \\
\hline
\end{tabular}

Karena nilai signifikasi yang diperoleh $0,447>0,05$ maka $\mathrm{H}_{0}$ diterima, sehingga data kedua kelas tersebut homogen

Karena data tersebut normal dan homogen, maka langkah selanjutnya yang dilakukan adalah menganalisis perbedaan rerata kedua kelas menggunakan uji t.

Tabel 9. Uji t Data Postes Kemampuan Pemecahan Masalah Matematis

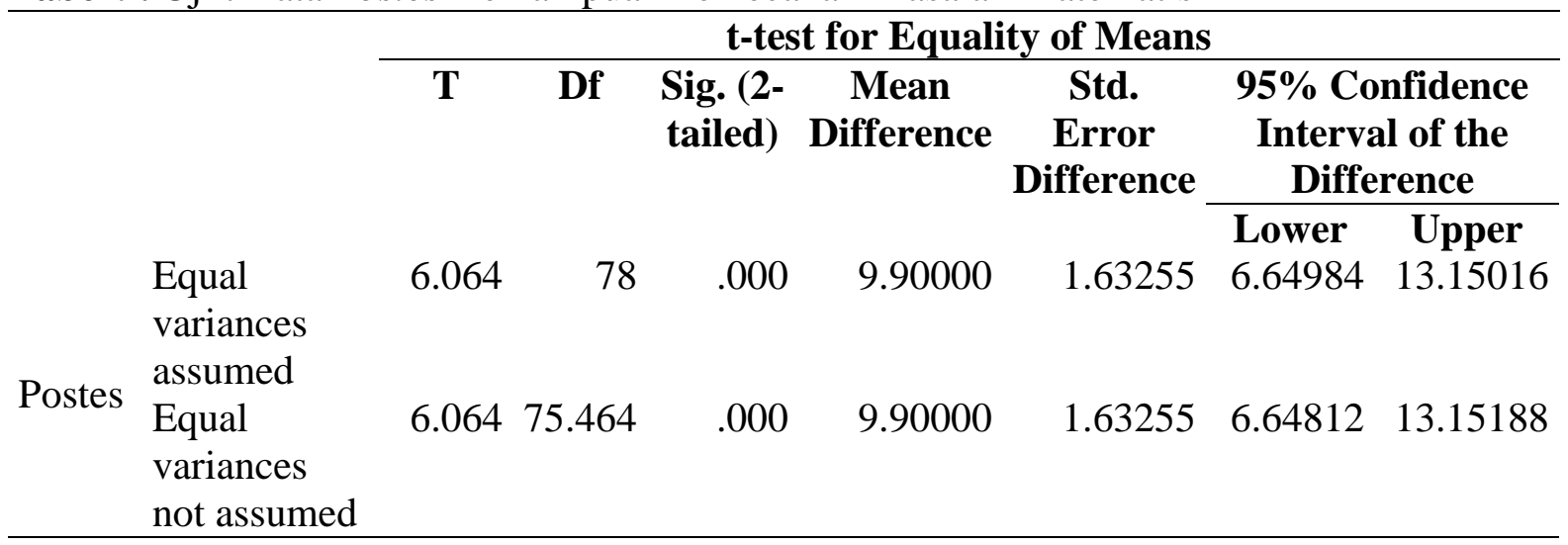

Dari tabel di atas terlihat bahwa nilai sig (2-tailed)nya $0,000<0,05$. Artinya rerata postes kemampuan pemecahan masalah matematis kelas eksperimen dan kelas kontrol berbeda. Dari hasil analisis dapat disimpulkan bahwa pada $\alpha=0,05$, terdapat perbedaan kemampuan awal pemecahan masalah matematis antara siswa kelas eksperimen dan kelas kontrol.

Hasil data gain ternormalisasi dianalisis untuk mengetahui mutu peningkatan kemampuan pemecahan masalah matematis matematis siswa yang menggunakan Problem Based Learning dan ekspositori. 
Tabel 10. Gain Ternormalisasi Kemampuan Pemecahan Masalah Matematis

\begin{tabular}{llrr}
\hline & & GainNormalEksperimen & GainNormalKontrol \\
\hline $\mathrm{N}$ & Valid & 40 & 40 \\
& Missing & 55 & 55 \\
Mean & & .5490 & .4695 \\
Median & .5650 & .4950 \\
Std. Deviation & .15040 & .13056 \\
Variance & .023 & .017 \\
Range & .65 & .56 \\
Minimum & .24 & .11 \\
Maximum & .89 & .67 \\
Sum & 21.96 & 18.78 \\
\hline
\end{tabular}

Berdasarkan tabel di atas, rerata gain ternormalisasi kelas eksperimen dan kelas kontrol berbeda, namun tidak terlalu jauh, selisihnya 0,795. Rerata gain normal kelas eksperimen $(0,5490)$ lebih tinggi dibandingkan kelas kontrol $(0,4695)$. Berdasarkan kriteria Hake (1999) gain normal keduanya berada pada kategori sedang. Untuk melihat peningkatannya signifikan atau tidak, maka dilakukan tahap kedua yaitu analisis statistik parametrik, diantaranya uji normalitas dan homogenitas data.

Tabel 11. Uji Normalitas Data Gain Ternormalisasi Kemampuan Pemcahan Masalah Matematis

\begin{tabular}{lrrr}
\hline & \multicolumn{3}{c}{ Shapiro-Wilk } \\
\cline { 2 - 4 } & Statistic & Df & Sig. \\
\cline { 2 - 4 } Gain Normal Eksperimen & .980 & 40 & .685 \\
Gain Normal Kontrol & .950 & 40 & .076 \\
\hline
\end{tabular}

Nilai signifikansi kelas eksperimen dan kelas kontrol masing-masing 0,685 dan 0,076. Nilai signifikansi keduanya lebih besar dari 0,05 artinya data gain ternormalisasi kelas eksperimen dan kelas kontrol berdistribusi normal.

Tabel 12. Uji Homogenitas Data Gain Ternormalisasi Kemampuan Pemecahan Masalah Matematis

\begin{tabular}{llllllr}
\hline Levene Statistic & & df1 & & df2 & & Sig. \\
\hline & 2.150 & & 1 & & 78 & .147 \\
\hline
\end{tabular}

Karena nilai signifikasi yang diperoleh $0,147>0,05$, maka data gain ternormalisasi kedua kelas tersebut homogen. Karena data tersebut normal, langkah selanjutnya dilakukan 
adalah menguji hipotesis komparatif mengenai peningkatan kemampuan pemecahan masalah matematis siswa pada kelas kontrol dan eksperimen menggunakan uji t'.

Tabel 13. Uji t' Data Gain Ternormalisasi Kemampuan Pemecahan Masalah Matematis

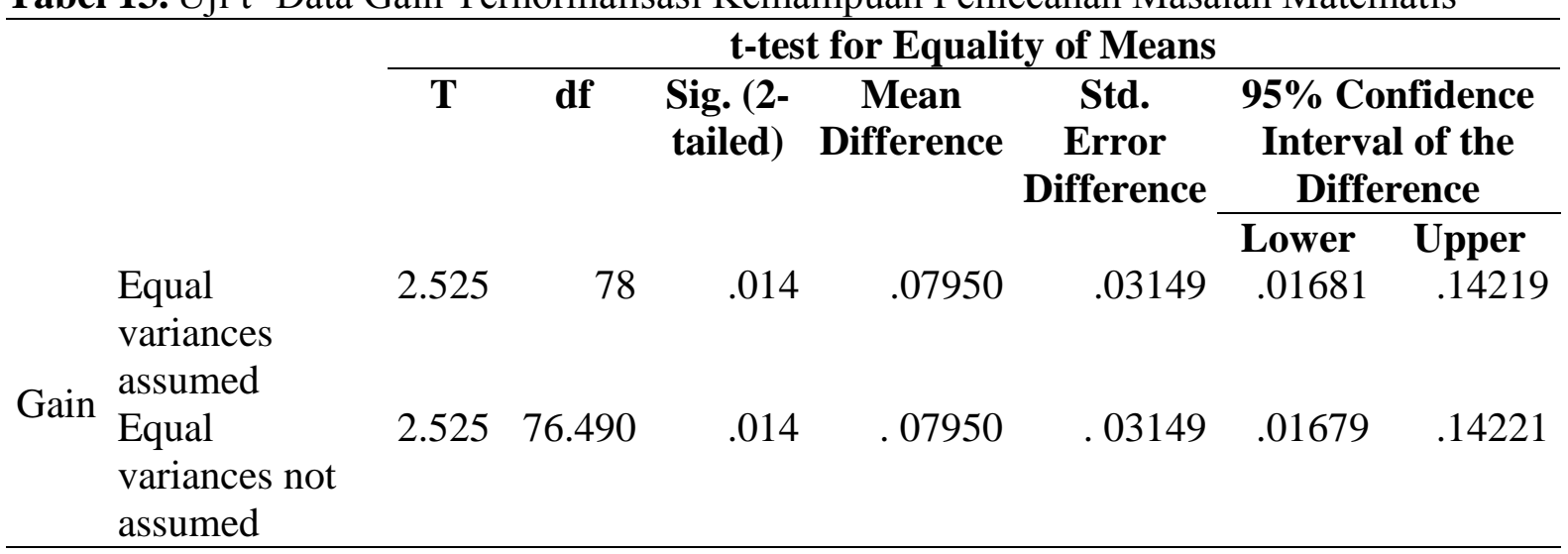

Dari tabel di atas terlihat bahwa nilai sig (2-tailed) pada Gain Equal Variances Not Assumed 0,000, sehingga nilai $\frac{\text { sig }(2-\text { tailed }}{2}=0,014<0,05$. Artinya rerata gain kemampuan pemecahan masalah matematis kelas eksperimen lebih besar daripada kelas kontrol. Sehingga dapat disimpulkan bahwa pada $\alpha=0,05$, peningkatan kemampuan pemecahan masalah matematis siswa yang menggunakan Problem Based Learning lebih baik daripada yang menggunakan pembelajaran ekspositori.

Tabel 14. Angket Skala Kecemasan Matematika Siswa Sebelum dan Sesudah Pembelajaran Menggunakan Problem Based Learning

\begin{tabular}{lrrr}
\hline & & Sebelum & Sesudah \\
\hline $\mathrm{N}$ & Valid & 40 & 40 \\
& Missing & 0 & 0 \\
Mean & & 107.03 & 145.38 \\
Median & 109.00 & 147.00 \\
Std. Deviation & 7.492 & 14.602 \\
Variance & 56.128 & 213.215 \\
Range & 35 & 66 \\
Minimum & 87 & 109 \\
Maximum & 122 & 175 \\
Sum & 4281 & 5815 \\
\hline
\end{tabular}

Dari tabel di atas terlihat bahwa rerata skala kecemasan matematika siswa sesudah menggunakan Problem Based Learning lebih tinggi 38,35 dibandingkan sebelum 
menggunakan Problem Based Learning, itu artinya rerata kecemasan matematika setelah menggunakan Problem Based Learning mengalami penurunan.

Tabel 15. Hasil Uji Normalitas Data Kecemaan Matematika Sebelum dan Sesudah Pembelajaran

\begin{tabular}{lrrrrr}
\hline & \multicolumn{3}{c}{ Shapiro-Wilk } \\
\cline { 2 - 6 } & Statistic & Df & Sig. & \\
Sebelum & .966 & & 40 & & .274 \\
Sesudah & & .989 & & 40 & \\
\hline
\end{tabular}

Nilai signifikansi data kecemasan matematika siswa sebelum dan sesudah pembelajaran menggunakan Problem Based Learning adalah 0.274 dan 0,966. Nilai signifikansi keduanya lebih besar dari 0,05 sehingga $\mathrm{H}_{\mathrm{o}}$ diterima, artinya data kecemasan matematika siswa sebelum dan sesudah pembelajaran menggunakan Problem Based Learning berdistribusi normal.

Tabel 16. Hasil Uji t Data Kecemasan Matematika Siswa

\begin{tabular}{|c|c|c|c|c|c|c|c|c|c|}
\hline \multirow[b]{3}{*}{ Pair 1} & \multirow[b]{3}{*}{$\begin{array}{l}\text { Sebelum- } \\
\text { Sesudah }\end{array}$} & \multicolumn{5}{|c|}{ Paired Differences } & \multirow[b]{2}{*}{$\mathbf{t}$} & \multirow[b]{2}{*}{ df } & \multirow[b]{2}{*}{$\begin{array}{l}\text { Sig. (2- } \\
\text { tailed) }\end{array}$} \\
\hline & & Mean & $\begin{array}{c}\text { Std. } \\
\text { Deviation }\end{array}$ & $\begin{array}{l}\text { Std. } \\
\text { Error } \\
\text { Mean }\end{array}$ & \multicolumn{2}{|c|}{$\begin{array}{l}\text { 95\% Confidence } \\
\text { Interval of the } \\
\text { Difference }\end{array}$} & & & \\
\hline & & -38.350 & 11.358 & $\begin{array}{r}\text { Mean } \\
1.796\end{array}$ & $\begin{array}{l}\text { Lower } \\
-41.982\end{array}$ & $\begin{array}{l}\text { Upper } \\
-34.718\end{array}$ & -21.355 & 39 & .000 \\
\hline
\end{tabular}

Dari tabel di atas terlihat bahwa nilai sig (2-tailed) adalah 0,000, sehingga nilai $\frac{s i g(2-\text { tailed }}{2}=0,000<0,05$. Artinya rerata skor kecemasan matematika siswa sesudah pembelajaran menggunakan Problem Based Learning lebih baik daripada sebelum menggunakan pembelajaran Problem Based Learning. 
Tabel 17. Gain Ternormalisasi Data Kecemasan Matematika Siswa

\begin{tabular}{lrr}
\hline N & Valid & $\mathbf{4 0}$ \\
\cline { 2 - 3 } & Missing & 0 \\
Mean & & .4165 \\
Median & .4200 \\
Std. Deviation & .13053 \\
Variance & .017 \\
Range & .54 \\
Minimum & .19 \\
Maximum & .73 \\
Sum & .76 .66 \\
\hline
\end{tabular}

Pada tabel di atas terlihat bahwa rerata gain ternormalisasinya 0,41. Berdasarkan kriteria interpretasi Hake (1999) nilai rerata gain ternormalisasi tersebut masuk pada kategori sedang. Artinya setelah menggunakan Problem Based Learning kecemasan matematika siswa menurun, namun penurunanya pada kategori sedang.

Tabel 18. Contoh Hasil Pernyataan Angket Kecemasan Matematika

\begin{tabular}{ccc}
\hline Nama Subjek & Jumlah Pernyataan & Interprestasi \\
\hline Sis 1 & 135 & Kadang-Kadang Cemas \\
Sis 6 & 116 & Kadang-Kadang Cemas \\
Sis 12 & 175 & Tidak cemas \\
\hline
\end{tabular}

Pada tabel di atas hasil contoh hasil pernyataan respon oleh siswa. Rerata pada seluruh pernyataan angket kecemasan matematika yang di dapat reratanya sebesar 147,375, kalo dilihat dari interprestasi kecemasan matematika yang telah dibuat termasuk pada kategori kadang-kadang cemas. Artinya setelah menggunakan Problem Based Learning kecemasan matematika siswa menurun, namun penurunannya masuk pada kategori kadangkadang cemas. Untuk mengetahui ada tidaknya korelasi antara kecemasan matematika dan kemampuan pemecahan masalah siswa digunakan korelasi product moment.

Berdasarkan kinerja pengujian jika nilai probabilitas 0,05 lebih kecil atau sama dengan probabilitas sig. atau $(0,05 \leq$ sig), artinya tidak ada hubungan yang signifikan. Jika nilai probalitas 0,05 lebih besar atau sama dengan nilai probabilitas sig $(0,05 \geq \operatorname{sig})$, artinya ada hubungan yang signifikan (Riduwan, 2011). 
Tabel 19. Korelasi antara Kemampuan Pemecahan Masalah Matematis Siswa dan Kecemasan Matematika

\begin{tabular}{llcc}
\hline & & $\begin{array}{c}\text { Kemampuan } \\
\text { Pemecahan Masalah } \\
\text { Matematis }\end{array}$ & $\begin{array}{c}\text { Kecemasan } \\
\text { Matematika }\end{array}$ \\
\hline $\begin{array}{l}\text { Kemampuan Pemecahan } \\
\text { Masalah Matematis }\end{array}$ & Pearson & 1 & $.957^{* *}$ \\
& Sorrelation & & .000 \\
& Sig. (2-tailed) & 40 & 40 \\
Kecemasan Matematika & Pearson & $.957^{* *}$ & 1 \\
& Correlation & & \\
& Sig. (2-tailed) & .000 & 40 \\
& $\mathrm{~N}$ & 40 & \\
\hline
\end{tabular}

Pada tabel korelasi di atas diperoleh varibel pemecahan masalah matematis siswa dan kecemasan matematika nilai sig. sebesar 0,000 , kemudian dengan probabilitas 0,05 , ternyata nilai probalitas 0,05 lebih besar dari nilai probabilitas sig. atau $0,05 \geq 0,000$ ), artinya signifikan. Terbukti bahwa kemampuan pemecahan masalah matematis siswa mempunyai hubungan secara signifikan terhadap kecemasan matematis siswa.

\section{KESIMPULAN}

Berdasarkan hasil pengolahan data dan temuan yang diperoleh dalam penelitian ini adalah sebagai berikut:

1. Peningkatan kemampuan pemecahan masalah matematis siswa dengan Problem Based Learning lebih baik daripada siswa dengan pembelajaran ekspositori.

2. Kualitas peningkatan kemampuan pemecahan masalah matematis siswa yang menggunakan Problem Based Learning lebih baik daripada siswa dengan pembelajaran ekspositori.

3. Penurunan kecemasan matematika siswa dengan Problem Based Learning lebih baik daripada siswa dengan pembelajaran ekspositori.

4. Tingkat kecemasan siswa yang menggunakan Problem Based Learning menurun dibandingkan dengan siswa yang menggunakan pembelajaran ekspositori. Hal ini dapat mempercepat siswa untuk memahami kemampuan pemecahan masalah matematis siswa.

5. Korelasi antara kemampuan pemecahan masalah dengan kecemasan matematika peserta didik positif dan signifikan, dilihat dari hasil penelitian yang telah dilakukan. Dimana 
terdapat penurunan tingkat kecemasan pada pembelajaran matematika dan peningkatan kemampuan pemecahan masalah.

Dengan demikian, model Problem-Based Learning secara keseluruhan mampu menurunkan tingkat kecemasan matematika dan meningkatkan kemampuan pemecahan masalah pada siswa.

\section{DAFTAR PUSTAKA}

Creswell, J W, (2010). Research Design pendekatan Kualitatif, Kuantitatif, dan Mixed. Yogyakarta: Pustaka Pelajar.

Depdiknas, (2006). Permendiknas No. 22 tahun 2006 tentang Standar Isi untuk Satuan Pendidikan Dasar dan Menengah, Jakarta: Direktorat Menejemen Pendidikan Dasar dan Menengah.

Hake, R.R. (1999). Analizing Change Gain Scores. 17 Oktober 2013. http//www physics indiana edu/-sdi/AnalizingChange-Gain.

Ibrahim,(2000). Pembelajaran Berbasis Masalah. Surabaya UNESA University Press.

Kunter, (1992, Agustus 13). Teachers and Parents Who Are Afraid Of Math Can Pass that Anxiety to The Next Generation. The New York Times, p.B4, C12.

Riduwan. (2011). Cara Mudah Belajar SPSS 17.0 dan Aplikasi Statistik Penelitian. Bandung: Alfabeta.

Richardson, F.C. dan Suinn, R.M. (1972). The Mathematics Anxiety Rating Scale Psychometric Data. Journal of Counseling Psychology, 19 (6), p.551-554.

Ruseffendi, E.T. (2006). Pengantar kepada Membantu Guru Mengembangkan Kompetensinya dalam Pengajaran Matematiak untuk Meningkatkan CBSA. Bandung: Tarsito.

Yaniawati, P. (2001). E-learning: Alternatif Pembelajaran Kontemporer, Bandung: Arfino Raya. 